\title{
Riluzole: real-world evidence supports significant extension of median survival times in patients with amyotrophic lateral sclerosis
}

This article was published in the following Dove Press journal:

Degenerative Neurological and Neuromuscular Disease

29 May 2017

Number of times this article has been viewed

\author{
Michael Hinchcliffe' \\ Alan Smith² \\ 'Paracelsis Ltd, ${ }^{2}$ PharmaSci Consulting \\ Ltd, Nottingham, UK
}

\begin{abstract}
Amyotrophic lateral sclerosis (ALS) is the commonest form of motor neuron disease and is a fatal, degenerative, multisystem disorder affecting upper and/or lower motor neurons in the motor cortex, brain stem, and spinal cord. ALS is characterized by progressive atrophy of associated bulbar, limb, thoracic, and abdominal muscles and supporting cells manifesting in a range of muscular symptoms such as weakness and wasting and eventual paralysis; the majority of patients will die from respiratory failure within 2-5 years of onset. Riluzole, a synthetic benzothiazole drug with glutamine antagonist activity, is indicated for the treatment of patients with ALS and is the only drug that has been shown to slow the course of the disease and extend survival in ALS patients. The original analyses, and subsequent meta-analyses, of data obtained from randomized controlled trials (RCTs) suggest that riluzole typically extends survival by $2-3$ months and increases the chance of an additional year of survival by $\sim 9 \%$. However, published real-world evidence (RWE) from 10 clinical ALS databases indicates that riluzole therapy may afford much greater extension of survival, and improvements in median survival times of more than 19 months have been reported in the overall ALS patient population. This article will review the available data from RCTs and RWE on riluzole therapy.
\end{abstract}

Keywords: ALS, survival, randomized controlled trial, RCT, RWE

\section{Introduction}

Riluzole (chemical name: 2-amino-6-(trifluoromethoxy)benzothiazole, CASRN: 1744-22-5, molecular formula: $\mathrm{C}_{8} \mathrm{H}_{5} \mathrm{~F}_{3} \mathrm{~N}_{2} \mathrm{OS}$, molecular weight: 234.2) is a synthetic benzothiazole drug with glutamine antagonist activity. ${ }^{1,2}$ Riluzole is indicated for the treatment of patients with amyotrophic lateral sclerosis (ALS) and extends survival and/ or time to mechanical ventilation (tracheostomy with noninvasive ventilation) (current ATC code: N07XX02; pharmacotherapeutic group: other nervous system drugs). ${ }^{1,3,4}$

\section{ALS}

ALS is the commonest form of motor neuron disease and is a fatal, degenerative, multisystem disorder affecting upper and/or lower motor neurons in the motor cortex, brain stem, and spinal cord. ${ }^{5-12}$ The disease is characterized by progressive atrophy of associated bulbar (mouth and throat), limb, thoracic, and abdominal muscles and supporting cells resulting in a range of muscular symptoms such as weakness, wasting, pain, spasticity, spasms, cramps, and eventual paralysis. Most patients will die from respiratory failure within 2-3 years in the case of bulbar-onset ALS and 3-5 years in the case of limb-onset ALS cases; however, 5-10\% of patients may die prematurely or
Correspondence: Michael Hinchcliffe Paracelsis Ltd, BioCity Nottingham, Pennyfoot Street, Nottingham, Nottinghamshire NGI IGF, UK Tel: +44 II 58882842

Emailmh@paracelsis.com 
survive for a decade or longer. ${ }^{6,710,12}$ Bulbar symptoms such as dysarthria (speech disturbance) and dysphagia (difficulties or discomfort in swallowing) are frequently observed, especially in the late stages of the disease. ${ }^{5-7}$ Cognitive dysfunction may occur in $20-50 \%$ of ALS cases, and $5-15 \%$ of patients develop dementia.

Approximately $10 \%$ of all ALS patients have a familial form of the disease (FALS) attributable to a gene mutation. ${ }^{6,7-12}$ In the absence of family history, the disease is usually classified as sporadic ALS (SALS). The mean age at onset of SALS is 58-63 years compared to 40-60 years for FALS. In Europe, the annual median incidence (the rate of new or newly diagnosed cases) and prevalence (the actual number of live cases) of ALS per 100,000 population have been estimated at 2.08 and 5.40 , respectively, corresponding to $\sim 40,000$ prevalent cases..$^{13}$ In the US, the estimated annual incidence and prevalence have been reported as 1.75 and $5.0(\sim 16,000$ prevalent cases), respectively. ${ }^{13,14}$ Globally, the overall pooled annual incidence of ALS is $\sim 1.9 / 100,000$ population, and it is estimated that there are presently $\sim 228,000$ prevalent cases. ${ }^{15}$

The etiology and pathogenesis of motor neuron degeneration in ALS are unknown, but there is a consensus that persons are rendered susceptible through a complex combination of factors, possibly involving multiple genes and/or environmental exposures. ${ }^{16}$ However, few genetic or environmental risks have been discovered to date. Among other factors such as mitochondrial dysfunction, protein aggregation, generation of free radicals, inflammation, and apoptosis, there is suggestion of an association with excessive and uninterrupted release of excitatory amino acids, principally glutamate, from presynaptic nerve terminals in the CNS leading to overstimulation of postsynaptic glutamate receptors ("excitotoxicity"). ${ }^{6,16-18}$ Excitotoxicity is accompanied by massive calcium and sodium ion influx into neurons via glutamate receptor-gated ion channels accompanied by passive movement of chloride ions and water. The combination of increased calcium ions and intracellular volume induces various lethal metabolic pathways, for example, the overproduction of free radicals such as nitric oxide, as well as swelling to internal organelles and failure of the plasma membrane, leading to necrosis and eventual death of the neuron. The diagnosis of ALS is based largely on characteristic clinical signs and symptoms observed in the patient in conjunction with the conduct of specialized clinical tests, such as electromyography (EMG) and magnetic resonance imaging (MRI), designed to exclude conditions that may produce similar signs/symptoms. ${ }^{6,16,19} \mathrm{It}$ is reported that diagnosis error can occur in $5-10 \%$ of ALS cases. ${ }^{6}$ To improve the diagnosis of ALS, the El Escorial diagnostic criteria were developed by the World Federation of Neurology (WFN) in 1994 and form the basis for the recruitment of ALS patients into clinical trials. Recent revisions to the El Escorial criteria have been recommended to include more quantitative and objective measures to facilitate more accurate diagnosis and recruitment of ALS patients, in particular early-stage patients, into clinical trials. ${ }^{19}$

\section{Riluzole}

Riluzole was approved for the treatment of ALS, in the form of oral tablets, by the FDA in 1995 and subsequently licensed for use in other territories including the European Union (EU). ${ }^{20}$ The drug was approved by the National Institute for Health and Care Excellence (NICE) in 2001 for use in motor neuron disease in the UK. ${ }^{21}$

Riluzole is the only drug licensed to treat ALS and the only drug to date that has been shown to slow the course of the disease and extend survival in ALS patients. Being a glutamate antagonist, "antiexcitotoxic" action is thought to be a prominent feature of its mechanism of action. ${ }^{20,22}$ Guidelines published by the European Federation of Neurological Sciences (EFNS) advocate initiation of riluzole therapy as soon as possible after diagnosis of ALS. ${ }^{7}$ The recommended dose is $50 \mathrm{mg}$ twice daily, taken 1 hour before or 2 hours after a meal.

In the UK, riluzole is available as $50 \mathrm{mg}$ film-coated tablets (Rilutek ${ }^{\circledR}$ from Sanofi, Guildford, UK, Riluzole Actavis from Actavis UK Ltd, a subsidiary of Accord Healthcare Ltd., Barnstaple, UK, and Riluzole SUN from Ranbaxy (UK) Ltd a Sun Pharmaceutical Company, Hayes, UK) ${ }^{23}$ More recently, a novel, patented, oral liquid presentation of riluzole, Teglutik ${ }^{\circledR}$ $5 \mathrm{mg} / \mathrm{mL}$ oral suspension (Martindale Pharma, Romford, UK), has been introduced. ${ }^{23-25}$ The oral suspension is reported to offer advantages in the treatment of ALS since dysphagia is present in around one-third of patients at onset and over $80 \%$ will develop this condition and/or need enteral feeding in later stages of the disease, regardless of whether the onset is "bulbar" or "limb". The oral suspension potentially allows patients to continue riluzole therapy for longer.

\section{Efficacy of riluzole for the treatment of ALS: randomized controlled trials (RCTs)}

A comprehensive search of open published information on "Riluzole" (1990-2017) has been performed using PubMed, Scopus, Cochrane Central Register of Controlled Trials (CENTRAL), and Google Scholar bibliographic databases. The PubMed search generated 127 articles related to "Clinical Trial" and "Humans". Scopus generated 1,485 articles related to "Medicine" and "Clinical Trial". The Central search produced 192 results for "Riluzole", and Google Scholar 
identified 5,210 articles related to "Clinical Trial". From the searches, four key publications related to RCTs conducted on riluzole in ALS patients were identified: these studies were reported by Bensimon et al, ${ }^{26}$ Lacomblez et al, ${ }^{27}$ Yanagisawa et $\mathrm{al}^{28}$ and Bensimon et $\mathrm{al}^{29}$ between 1994 and 2002: subsequently no new RCTs appear to have been conducted on riluzole in ALS patients. Additional RCTs, conducted to investigate other potential indications such as autistic disorder, cervical myelopathy, and chronic schizophrenia, are discounted for this review. ${ }^{30-32}$

Details of the survival outcomes from the four RCTs conducted on riluzole in ALS patients are provided in Table 1. It should be noted that the specific focus of this manuscript is survival outcomes and the reader is directed

Table I Summary of survival outcomes of randomized controlled trials conducted on riluzole in ALS patients

\begin{tabular}{|c|c|c|c|c|}
\hline Parameters & Bensimon et $\mathrm{al}^{26}$ & Lacomblez et al $^{27,59, a}$ & Bensimon et $\mathrm{al}^{29}$ & Yanagisawa et $\mathrm{al}^{28}$ \\
\hline Treatment/comparator & $\begin{array}{l}\text { Riluzole } 100 \mathrm{mg} / \mathrm{d} / \\
\text { placebo }\end{array}$ & $\begin{array}{l}\text { Riluzole } 50,100 \text {, and } 200 \mathrm{mg} / \mathrm{d} / \\
\text { placebo }\end{array}$ & $\begin{array}{l}\text { Riluzole } 100 \mathrm{mg} / \mathrm{d} / \\
\text { placebo }\end{array}$ & $\begin{array}{l}\begin{array}{l}\text { Riluzole } 100 \mathrm{mg} / \mathrm{d} / \\
\text { placebo }\end{array} \\
\end{array}$ \\
\hline Design/randomized?/double-blind?/ITT? & RCT/yes/yes/yes & RCT/yes/yes/yes & RCT/yes/yes/yes & RCT/yes/yes/yes \\
\hline Country/number of centers & France, Belgium/7 & $\begin{array}{l}\text { France, Belgium, UK, Spain, } \\
\text { Germany, USA, Canada/30 }\end{array}$ & France, Belgium/9 & Japan/48 \\
\hline End of study & 21 months & 18 months & 18 months & 21 months \\
\hline No. patients: (total) placebo/riluzole & (155) 78/77 & \begin{tabular}{|l|} 
(959) 242/7/7 (riluzole: \\
$237 / 236 / 244$, respectively)
\end{tabular} & (168) 86/82 & (195) 97/98 \\
\hline \multicolumn{5}{|c|}{ Comparison of all ALS cases (data relate to end of study unless otherwise stated) } \\
\hline $\begin{array}{l}\text { Median tracheostomy-free survival } \\
\text { time (placebo/riluzole) }\end{array}$ & I4.9/I7.7 months & I3.5/16.5 months & NR & \multirow[t]{4}{*}{ NR } \\
\hline Reduction in mortality with riluzole & $\begin{array}{l}12 \text { months: } 38.6 \% \text {; end of } \\
\text { study } 19.4 \%\end{array}$ & NR & & \\
\hline $\begin{array}{l}\text { Unadjusted RR [or } \mathrm{HR} \text { ] }(95 \% \mathrm{Cl}) \text { of } \\
\text { tracheostomy-free survival }\end{array}$ & NR & $\begin{array}{l}\text { All doses pooled } 0.8 \mathrm{I}(0.66-0.99) \\
p=0.048 ; 50 \mathrm{mg} / \mathrm{d} 0.85(0.66-\mathrm{I} . \mathrm{II}) \\
p=0.25 ; 100 \mathrm{mg} / \mathrm{d} 0.79(0.6-\mathrm{I} .02) \\
p=0.076 ; 200 \mathrm{mg} / \mathrm{d} 0.79(0.6 \mathrm{I}-\mathrm{I} .03) \\
p=0.075 \text { (log-rank) }\end{array}$ & $\begin{array}{l}{[1.05(0.73-1.50)} \\
p=0.77]\end{array}$ & \\
\hline $\begin{array}{l}\text { Adjusted RR }(95 \% \mathrm{Cl}) \text { of } \\
\text { tracheostomy-free survival using Cox } \\
\text { proportional hazard method }\end{array}$ & $\begin{array}{l}\text { I } 2 \text { months: } 0.43 \\
(0.24-0.77) p=0.005 ; \text { end } \\
\text { of study: } 0.66(0.42-1.02) \\
p=0.058\end{array}$ & $\begin{array}{l}\text { All doses pooled } 0.67(0.54-0.83) \\
p=0.0003 ; 50 \mathrm{mg} / \mathrm{d} 0.76(0.59-0.99) \\
p=0.04 ; 100 \mathrm{mg} / \mathrm{d} 0.65(0.50-0.85) \\
p=0.002 ; 200 \mathrm{mg} / \mathrm{d} 0.61(0.47-0.80), \\
p=0.0004\end{array}$ & NR & \\
\hline \multicolumn{5}{|l|}{ Meta-analyses by Stewart et al ${ }^{33}$} \\
\hline \multicolumn{5}{|c|}{ Comparison of all ALS cases - riluzole 50, 100, and $200 \mathrm{mg} / \mathrm{d}$ vs. placebo: unadjusted tracheostomy-free survival } \\
\hline No. placebo/riluzole events & 49 of $78 / 39$ of 77 & 120 of $242 / 311$ of 717 & 64 of $86 / 60$ of 82 & \multirow[t]{2}{*}{ NR } \\
\hline $\mathrm{HR}(95 \% \mathrm{Cl})$ & $0.64(0.4 \mathrm{I}-1.00) p=0.050^{\mathrm{b}}$ & $0.80(0.63-1.0 I) p=0.058^{b}$ & $\begin{array}{l}0.98(0.66-1.46) \\
p=0.93\end{array}$ & \\
\hline Pooled data\#I weight (\%) & 15.9 & 59.0 & 25.1 & 0.0 \\
\hline $\mathrm{HR}(95 \% \mathrm{Cl})$ & \multicolumn{3}{|l|}{$0.83(0.69-0.99)^{\mathrm{b}}$} & NA \\
\hline Pooled data\#2 weight (\%) & 21.3 & 78.7 & 0 & 0 \\
\hline $\mathrm{HR}(95 \% \mathrm{Cl})$ & \multicolumn{2}{|l|}{$0.76(0.62-0.94)^{b}$} & NA & NA \\
\hline \multicolumn{5}{|c|}{ Comparison of bulbar onset ALS cases - riluzole $100 \mathrm{mg} / \mathrm{d}$ vs. placebo: unadjusted tracheostomy-free survival or [progression-free survival] } \\
\hline Placebo/Riluzole events & 14 of $17 / 7$ of 15 & & 20 of $28 / 28$ of 29 & [19 of $28 / 20$ of 28$]$ \\
\hline $\mathrm{HR}(95 \% \mathrm{Cl})$ & $0.29(0.1 \mathrm{I}-0.75) p=0.010^{\mathrm{b}}$ & NR & $\begin{array}{l}1.94(1.08-3.50) \\
p=0.025\end{array}$ & $\begin{array}{l}{[1.05(0.53-2.09)]} \\
p=0.891\end{array}$ \\
\hline \multicolumn{5}{|c|}{ Comparison of limb onset ALS cases - riluzole $100 \mathrm{mg} / \mathrm{d}$ vs. placebo: unadjusted tracheostomy-free survival or [progression-free survival] } \\
\hline Placebo/riluzole events & 35 of $61 / 32$ of 62 & NR & 44 of $58 / 32$ of 53 & \begin{tabular}{|l|} 
[Early limb 23 of \\
$36 / 27$ of 42 ] \\
[Advanced limb 24 \\
of $33 / 24$ of 28 ] \\
\end{tabular} \\
\hline $\mathrm{HR}(95 \% \mathrm{Cl})$ & $0.80(0.48-1.33) p=0.394^{b}$ & NR & $\begin{array}{l}0.73(0.46-1.15) \\
p=0.173\end{array}$ & $\begin{array}{l}\text { Early limb I.07 } \\
(0.58-1.97)] \\
p=0.82 \mathrm{I} \\
\text { [Advanced limb } \\
\mathrm{I} .48(0.76-2.87)] \\
p=0.247\end{array}$ \\
\hline
\end{tabular}

Notes: ${ }^{a}$ Data used for post hoc analysis in $24 I$ placebo and 713 riluzole ALS patients reported significant prolongation of milder health states in patients taking riluzole $(p<0.05) .{ }^{60}$ b Favors riluzole treatment.

Abbreviations: ALS, amyotrophic lateral sclerosis; Cl, confidence interval; HR, hazard ratio; ITT, intention-to-treat; NA, not applicable; NP, not performed; NR, not reported; RCT, randomized controlled trial; RR, relative risk. 
to original publications on the RCTs as well as those relating to meta-analyses for pertinent information on the effect of riluzole on functional measures and adverse effects/serious adverse effects. ${ }^{8,26-29,33}$ Collectively, the RCTs demonstrate a beneficial effect on bulbar and limb function, but no effect on muscle strength, in ALS patients while adverse effects have tended to be relatively minor. ${ }^{8}$

Data from the RCTs and subsequent meta-analyses (see subsequent paragraph) indicate that riluzole typically extends survival by 2-3 months and increases the chance of an additional year of survival by $\sim 9 \%{ }^{8,33}$ A perception may exist that prolongation of survival and benefit afforded through riluzole use are modest. ${ }^{8,9,33}$ Such negative connotations could arguably influence prescriber and patient choices alike. Nevertheless, some have concluded that riluzole "represents a significant therapeutic milestone in the treatment of a disease refractory to all previous treatments". ${ }^{34}$ It should also be borne in mind that the above-mentioned survival data do not take into consideration patients who survived longer than the 18- to 21-month follow-up period in the RCTs, and it is possible that the additional data would have positively impacted on median survival times in the riluzole group. Indeed, modeling based on the original RCT data estimated survival times with riluzole use of 21.38 months compared to 19.67 months with placebo using Weibull extrapolation. ${ }^{33}$ Reanalysis based on additional follow-up data obtained from the Lacomblez et $\mathrm{al}^{27}$ trial predicted survival times of 26.15 vs. 20.03 months using a Weibull model and 25.44 vs. 17.98 months using a Gompertz model, respectively. The authors advised caution in interpreting these data, but over a decade on, there is substantial support for prolongation of survival times in ALS patients following riluzole therapy based on retrospective and prospective studies utilizing clinical databases (see subsequently).

The use of riluzole in the treatment of ALS has been the subject of several Cochrane reviews, the most recent of which was published in 2012. ${ }^{8}$ Meta-analysis was conducted on data obtained from clinical trials to examine the efficacy of riluzole in prolonging survival and in delaying the use of surrogates (tracheostomy and mechanical ventilation). The same four RCTs met reported criteria and acceptable methodological quality, representing a total of 974 ALS patients treated with riluzole and 503 with placebo. The primary outcome variable was the pooled hazard ratio (HR), based on percentage of mortality (or tracheostomy) for $100 \mathrm{mg} / \mathrm{d}$ riluzole vs. placebo over all time points. Data from different studies and doses were pooled as appropriate, but those data presented by Yanagisawa et $\mathrm{al}^{28}$ were discounted from the meta-analysis as full trial details, and numerical data were unavailable.
In primary analyses, riluzole $100 \mathrm{mg} / \mathrm{d}$ was demonstrated to provide a slight benefit for the homogeneous group of patients originating from the Bensimon et $\mathrm{al}^{26}$ and Lacomblez et al ${ }^{27}$ trials; HR (with $95 \%$ confidence interval [CI]) of tracheostomy-free survival over all time points was $0.80(0.64-0.99 ; p=0.042)$, and there was no evidence of heterogeneity ( $p=0.33$ ). When the $100 \mathrm{mg} / \mathrm{d}$ data from the two trials were pooled, the median survival was 15.5 months in riluzole treated and 13.2 months in placebo treated (difference of 2.3 months). In the third trial, which included older and more seriously affected patients ${ }^{29}$, there was evidence of heterogeneity $(p<0.0001)$ in the results (i.e., worse survival in the third trial). However, despite the heterogeneity, there was only a slight impact on the overall treatment effect; HR $0.84(0.698-0.997 ; p=0.046)$. This represented an increased median survival from 11.8 to 14.8 months and 9\% gain in the probability of surviving 1 year (49\% placebo vs. $58 \%$ riluzole). A combination of data obtained for all riluzole doses (i.e., 50, 100, and $200 \mathrm{mg} / \mathrm{d}$ ) from the two homogeneous studies demonstrated a median survival of 17.2 months in riluzole treated and 15.5 months in placebo treated (difference of 1.7 months); HR 0.80 (0.66-0.95; $p=0.013)$.

In the secondary analyses, combination of the three trials showed that there was a significant survival advantage with riluzole treatment at 12 months (relative risk with 95\% CI: $0.78,0.65-0.92 ; p=0.0036$ ) but not at 18 months (relative risk: $0.92,0.83-1.02 ; p=0.12$ ). The Cochrane review concluded that riluzole $100 \mathrm{mg}$ daily is "reasonably safe and probably prolongs median survival by $\sim 2-3$ months" in patients with ALS. ${ }^{8}$ It was also reported that the absolute reduction in the risk of death at 12 months following treatment with $100 \mathrm{mg} / \mathrm{d}$ riluzole was $9 \%$ and that the number-needed-to-treat (NNT) was 11 (i.e., 11 ALS patients needed to be treated with $100 \mathrm{mg} / \mathrm{d}$ riluzole to delay one death until after 12 months). Based on calculations made from available RCT data, more favorable NNTs of 9, 7, and 6 have been reported by others for the overall ALS patient population. ${ }^{35-37}$

Meta-analyses on the four RCTs have also been conducted to examine the clinical and cost-effectiveness of riluzole in the treatment of ALS (Table 1). ${ }^{33}$ The analysis included data from the above-mentioned three RCTs (at all riluzole dosages) as well as previously unavailable data from the Yanagisawa et $\mathrm{al}^{28}$ trial. Based on the latter, the authors estimated that the HR (with 95\% CI) of tracheostomy-free survival over all time points was $1.26(0.83-1.90)$, indicating better survival in placebo patients (for the other three RCTs, the combined HR was 0.83 [0.69-0.99]). Combined analysis of all four RCTs revealed a HR of 0.89 (0.75-1.05), 
demonstrating a small but positive benefit afforded through riluzole therapy. The combined HR for overall survival (as opposed to tracheostomy-free survival) was similar; 0.88 (0.73-1.05). The authors concluded that there was "limited evidence of a modest benefit in tracheostomy-free survival for patients taking riluzole" and called for more evidence of efficacy from existing trials, from ALS databases, as well as further clinical trials.

\section{Efficacy of riluzole for the treatment of ALS: real-world evidence (RWE)}

Subsequent to the RCTs published between 1994 and 2002, the search of open, published information on riluzole has revealed at least 10 independent retrospective and prospective studies utilizing clinical databases on ALS patients. The clinical trial datasets utilized in these studies comprise efficacy and safety data collected from patients in the "real-world" and outside of the confines of RCTs. Real-world data or RWE draw on a wide range of research methodologies/data sources, including patient registries, existing electronic health records, routinely collected administrative data, prospective or retrospective primary patient level data collection, and population health surveys. ${ }^{38}$ The promise of RWE to support the development of new medicines is gathering momentum, and its general merits will be considered before specifically discussing RWE with respect to riluzole.

In 2001, the (US) Institute of Medicine (IOM) program unit of the National Academies of Sciences, Engineering, and Medicine (now the Health and Medicines Division) outlined its vision for health care in the 21 st century. ${ }^{39}$ The report highlighted shortfalls in health care delivery systems and presented a strategy and action plan to foster innovation and deliver improvements. The IOM committee advocated the need to make clinical decisions based on sound scientific evidence obtained not only from RCTs but also from RWE.

The pharmaceutical industry has been slow to embrace the use of RWE, and RCTs have remained the gold standard for generating clinical data on efficacy and safety to support registration of new products and subsequent prescribing information. $^{38,39}$ It is a sobering thought that it takes, on average, 17 years to incorporate new knowledge generated in RCTs into best health care practice, and application is not consistent across all therapeutic areas. This may be due in part to the inherent limitations in data generated in RCTs, namely evaluation in a narrowly defined patient population with exclusion or control for factors that are inevitably relevant in the real-world setting. Despite such limitations, investigators still tend to favor RCTs because they are less subject to bias and confounders compared to real-world data. ${ }^{40-42}$

More than a decade on, the pharma industry looks set to embrace the use of RWE in a new era of health care innovation. ${ }^{43-47}$ Indeed, the use of RWE is key to ensure that the results obtained in RCTs translate into tangible benefits in the patient population, and data from both sources seem crucial in decision-making processes.

RWE, based largely on retrospective/prospective analysis of large (historic) patient databases, suggests significant enhancement of survival in riluzole-treated ALS patients compared to those who did not receive riluzole with the effect most notable in patients who started the medication early in the disease. An examination of RWE with specific focus on survival data obtained following treatment with riluzole is summarized subsequently; the survival outcomes of the various database studies are also provided in Table 2 . In each case, the term "nontreated" refers specifically to patients who did not receive riluzole treatment and "survival" refers to tracheostomy-free survival unless otherwise specified. As for the RCTs, the reader should again consult the original publications detailed subsequently for information related to the effect of riluzole on functional measures and adverse effects/serious adverse effects.

1. Meininger et al: ${ }^{48}$ retrospective comparison undertaken on 356 riluzole-treated ALS patients during the period 1995 to 1997 with 161 non-treated ALS patients during the period 1989 to 1991 (database total $n=517$ ). Unadjusted survival analysis (i.e., without adjustment for prognostic factors) demonstrated a significant difference in median survival times between riluzole-treated (18.4 months) and nontreated (12.4 months) ALS patients $(p<0.001$, log-rank test). Thus, the median extension of survival afforded through the use of riluzole in ALS patients was $\sim 6$ months.

2. Brooks et al: ${ }^{49}$ retrospective comparison undertaken on 51 riluzole-treated ALS patients with 241 nontreated ALS patients with disease onset before 1996 (database total $n=292$ ) and 112 riluzole-treated ALS patients with 65 nontreated ALS patients with disease onset after 1996 (database total $n=177$ ). Prior to 1996 , the unadjusted median survival times was 58.4 months in riluzoletreated patients and 47.7 months in nontreated patients (log-rank $p=0.1338$ ) (Table 2). In the period after 1996, the unadjusted median survival times was $>67$ months in riluzole-treated patients and 49.1 months in nontreated patients $(p=0.0438)$. The median survival times were almost identical in nontreated patients in the two epochs $(p=0.4823)$. Cox analysis revealed that extension of 
Table 2 Summary of survival outcomes based on real-world evidence on riluzole in ALS patients

\begin{tabular}{|c|c|c|c|c|c|}
\hline Parameters & Meininger et $\mathrm{al}^{48}$ & Brooks et $\mathrm{al}^{49}$ & Turner et $\mathrm{al}^{50}$ & Traynor et $\mathrm{al}^{4 \mathrm{I}}$ & Mitchell et al ${ }^{51}$ \\
\hline $\begin{array}{l}\text { Treatment/ } \\
\text { comparator }\end{array}$ & $\begin{array}{l}\text { Riluzole/nonriluzole } \\
\text { treated }\end{array}$ & $\begin{array}{l}\text { Riluzole/nonriluzole } \\
\text { treated }\end{array}$ & $\begin{array}{l}\text { Riluzole/nonriluzole } \\
\text { treated }\end{array}$ & $\begin{array}{l}\text { Riluzole/nonriluzole } \\
\text { treated }\end{array}$ & $\begin{array}{l}\text { Riluzole/nonriluzole } \\
\text { treated }\end{array}$ \\
\hline Design & $\begin{array}{l}\text { Retrospective investigation } \\
\text { on riluzole-treated vs. } \\
\text { nontreated patients }\end{array}$ & $\begin{array}{l}\text { Retrospective investigation } \\
\text { on riluzole-treated vs. } \\
\text { nontreated patients }\end{array}$ & $\begin{array}{l}\text { Prospective } \\
\text { investigation } \\
\text { of therapeutic } \\
\text { interventions } \\
\text { including riluzole }\end{array}$ & $\begin{array}{l}\text { Retrospective } \\
\text { investigation on } \\
\text { riluzole-treated } \\
\text { vs. nontreated } \\
\text { patients }\end{array}$ & $\begin{array}{l}\text { Retrospective } \\
\text { investigation on } \\
\text { riluzole-treated vs. } \\
\text { nontreated patients }\end{array}$ \\
\hline $\begin{array}{l}\text { Country of database } \\
\text { origin (database } \\
\text { range - years) }\end{array}$ & $\begin{array}{l}\text { ALS database - source not } \\
\text { reported (non-treated } \\
\text { |989-|99|; treated } \\
\text { 1995-1997) }\end{array}$ & $\begin{array}{l}\text { ALS database }- \text { North } \\
\text { America (Wisconsin) } \\
\text { (disease onset before }[<] \\
\text { or from }[\geq] \text { 1996) }\end{array}$ & $\begin{array}{l}\text { ALS database - } \\
\text { Kings College, UK } \\
(1990-2000)\end{array}$ & $\begin{array}{l}\text { ALS database - } \\
\text { Republic of Ireland } \\
(1996-2000)\end{array}$ & $\begin{array}{l}\text { ALS database } \\
\text { - Preston, UK } \\
(1980-2003)\end{array}$ \\
\hline $\begin{array}{l}\text { No. patients: (total) } \\
\text { nontreated/riluzole }\end{array}$ & (5I7) $161 / 356$ & $\begin{array}{l}<1996(292) 24 \mid / 5 I ; \geq 1996 \\
(177) 65 / I \mid 12\end{array}$ & (656) 349/299 & (246) $97 / 149$ & (475) $327 / 148$ \\
\hline $\begin{array}{l}\text { Median survival } \\
\text { time (with } 95 \% \mathrm{Cl} \text { if } \\
\text { given) in overall ALS } \\
\text { patient population: } \\
\text { nontreated/riluzole } \\
\text { [tracheostomy- } \\
\text { free survival unless } \\
\text { otherwise stated] }\end{array}$ & $\begin{array}{l}\text { I } 2.4 \text { months/ } 18.4 \text { months } \\
p<0.00 \text { I (log-rank); } \\
\text { survival from time of } \\
\text { diagnosis }\end{array}$ & $\begin{array}{l}<1996: 47.7(38.3-67) / 58.4 \\
(47.3->67) \text { months } \\
p=0.1338 \text { (log-rank); } \\
\geq 1996: 49.1 \text { (38.I-67)/>67 } \\
(>67->67) \text { months } \\
p=0.0438 ; \text { survival from } \\
\text { time of symptom onset }\end{array}$ & $\begin{array}{l}32(29-35) / 5 \text { I } \\
(43-59) \text { months } \\
p<0.000 \text { I (log- } \\
\text { rank); survival from } \\
\text { time of symptom } \\
\text { onset }\end{array}$ & $\begin{array}{l}\text { I0.I/I4.3 months; } \\
\text { survival from time } \\
\text { of diagnosis } \\
(p=0.32 \text { log-rank; } \\
p=0.015 \\
\text { Peto-test })^{\mathrm{a}}\end{array}$ & $\begin{array}{l}2.25(2.03-2.48) / 3.07 \\
(2.73-3.4 \mathrm{I}) \text { years; } \\
\text { survival from time } \\
\text { of onset; difference } \\
\text { in median survival } \\
\text { times (with } 95 \% \mathrm{Cl}) \\
\text { for non-treated: } \\
\text { HR I.66 (I.32-2.I2) } \\
\text { p<0.05 (log-rank) }\end{array}$ \\
\hline $\begin{array}{l}\text { Cox regression } \\
\text { analysis for riluzole } \\
\text { treated (unless } \\
\text { otherwise specified): } \\
\text { RR or HR (with 95\% } \\
\text { Cl) if reported }\end{array}$ & NR & $\begin{array}{l}\text { Riluzole use a significant } \\
\text { prognostic factor } p<0.000 \text { I }\end{array}$ & RR $0.48 p<0.000$ I & $\begin{array}{l}\text { HR for untreated } \\
\text { I.08 (0.78-I.48) } \\
p=0.64\end{array}$ & $\begin{array}{l}\text { HR for riluzole- } \\
\text { treated } 0.20(0.089- \\
0.46) \mathrm{p}<0.001\end{array}$ \\
\hline Parameters & Zoccolella et $\mathrm{al}^{52}$ & Lee et $\mathbf{a l}^{53}$ & $\begin{array}{l}\text { Georgoulopoulou } \\
\text { et } \mathrm{al}^{54}\end{array}$ & Knibb et $a^{55}$ & Chen et $\mathrm{al}^{56}$ \\
\hline $\begin{array}{l}\text { Treatment/ } \\
\text { comparator }\end{array}$ & $\begin{array}{l}\text { Riluzole/nonriluzole } \\
\text { treated }\end{array}$ & $\begin{array}{l}\text { Riluzole/nonriluzole } \\
\text { treated }\end{array}$ & $\begin{array}{l}\text { Riluzole/nonriluzole } \\
\text { treated }\end{array}$ & $\begin{array}{l}\text { Riluzole/ } \\
\text { nonriluzole treated }\end{array}$ & $\begin{array}{l}\text { Riluzole/nonriluzole } \\
\text { treated }\end{array}$ \\
\hline Design & $\begin{array}{l}\text { Prospective investigation } \\
\text { on riluzole-treated vs. } \\
\text { nontreated patients }\end{array}$ & $\begin{array}{l}\text { Retrospective population- } \\
\text { based investigation on the } \\
\text { effect of various factors } \\
\text { including riluzole }\end{array}$ & $\begin{array}{l}\text { Prospective } \\
\text { investigation } \\
\text { on clinical and } \\
\text { therapeutic } \\
\text { interventions } \\
\text { including riluzole }\end{array}$ & $\begin{array}{l}\text { Prospective } \\
\text { investigation } \\
\text { on clinical and } \\
\text { therapeutic } \\
\text { interventions } \\
\text { including riluzole }\end{array}$ & $\begin{array}{l}\text { Prospective } \\
\text { population-based } \\
\text { investigation on the } \\
\text { effect of various } \\
\text { factors including } \\
\text { riluzole }\end{array}$ \\
\hline Database source & $\begin{array}{l}\text { ALS database - Puglia, Italy } \\
\text { (1998-1999) }\end{array}$ & $\begin{array}{l}\text { ALS database - Taiwan } \\
\text { (1999-2008) }\end{array}$ & $\begin{array}{l}\text { ALS database } \\
\text { - Modena, Italy } \\
(2000-2009)\end{array}$ & $\begin{array}{l}\text { ALS database - } \\
\text { South East, UK } \\
(1990-2013)\end{array}$ & $\begin{array}{l}\text { ALS database - } \\
\text { China (2007-2013) }\end{array}$ \\
\hline $\begin{array}{l}\text { No. patients: (total) } \\
\text { nontreated/riluzole }\end{array}$ & (I26) 53/73 & $(I, I 49) 45 I / 698$ & (193) 60/133 & (575) $315 / 260$ & $(I, 540) I,|125 / 4| 5$ \\
\hline $\begin{array}{l}\text { Median survival } \\
\text { time (with } 95 \% \mathrm{Cl} \text { if } \\
\text { given) in overall ALS } \\
\text { patient population: } \\
\text { nontreated/riluzole } \\
\text { [tracheostomy- } \\
\text { free survival unless } \\
\text { otherwise stated] }\end{array}$ & $\begin{array}{l}\text { I2.4 }(0.3-50) / 18.3(1.8-48) \\
\text { months; }(p=0.78 \text { log-rank; } \\
p=0.09 \text { Peto-test })^{\mathrm{a}} \text { survival } \\
\text { from time of diagnosis }\end{array}$ & $\begin{array}{l}\text { Survival from time of } \\
\text { diagnosis; NR (textual } \\
\text { description only) }\end{array}$ & $\begin{array}{l}\text { Univariate analysis } \\
3 \mathrm{I}(25-46) / 38 \\
(35-43) \text { months } \\
p=0.1 \text { I (log-rank); } \\
\text { corresponding } \\
\text { survival time } \\
\text { to death: } 3 \text { I } \\
(25-46) / 43(37-5 \text { I) } \\
\text { months } p<0.0 \text { I; } \\
\text { survival time from } \\
\text { symptom onset }\end{array}$ & $\begin{array}{l}\text { Time from } \\
\text { diagnosis to } \\
\text { respiratory } \\
\text { involvement: } \\
\text { coefficient for } \\
\text { riluzole use: } 0.328 \\
(0.15-0.5 \mathrm{I}) \text { p<0.00 I } \\
\text { (log-rank) in bulbar } \\
\text { onset patients; } \\
0.408 \text { ( } 0.22-0.60) \\
p<0.000 \text { I in limb } \\
\text { onset patients }\end{array}$ & $\begin{array}{l}64.0(57.8- \\
70.2) / 67.0 \\
(54.7-79.3) \text { months } \\
p=0.780 \text { (log-rank). }\end{array}$ \\
\hline
\end{tabular}


Table 2 (Continued)

\begin{tabular}{|c|c|c|c|c|c|}
\hline Parameters & Zoccolella et al ${ }^{52}$ & Lee et $\mathbf{a l}^{53}$ & $\begin{array}{l}\text { Georgoulopoulou } \\
\text { et } \mathbf{a}^{54}\end{array}$ & Knibb et $\mathbf{a l}^{55}$ & Chen et $\mathrm{al}^{56}$ \\
\hline $\begin{array}{l}\text { Cox regression } \\
\text { analysis for riluzole } \\
\text { treated (unless } \\
\text { otherwise specified): } \\
\text { RR or HR (with 95\% } \\
\mathrm{Cl} \text { ) if reported }\end{array}$ & $\begin{array}{l}\text { RR } 0.5 \text { I }(0.25-1.03) \\
p<0.06\end{array}$ & $\begin{array}{l}\text { Unadjusted HR } 0.32(0.22- \\
0.45) p<0.00 \text { I; adjusted HR } \\
\text { for riluzole-treated } 0.34 \\
(0.24-0.49) p<0.001\end{array}$ & $\begin{array}{l}\text { Stratified analysis } \\
\text { median survival } \\
\text { times (nontreated/ } \\
\text { treated) in overall } \\
\text { population: } \\
\text { diagnosis <2006: } \\
3 \text { I/46 } p=0.16 \\
\text { (log-rank); diagnosis } \\
\geq 2006: 26 / 36 \\
p=0.21 \text {; Cox } \\
\text { analysis revealed } \\
\text { riluzole treatment } \\
\text { was independently } \\
\text { related to longer } \\
\text { survival ( } p<0.01 \text { ) }\end{array}$ & $\begin{array}{l}\text { Time from } \\
\text { diagnosis to } \\
\text { respiratory } \\
\text { involvement: } \\
\text { coefficient: } 0.228 \\
(0.077-0.380) \\
p=0.003 \text { in bulbar } \\
\text { onset patients; } \\
0.205 \text { ( } 0.057- \\
0.353) p=0.006 \text { in } \\
\text { limb onset patients }\end{array}$ & $\begin{array}{l}\text { HR } 0.855 \\
(0.685-1.068) \\
p=0.167 \\
\text { Subgroups: }{ }^{b} H R \\
>Q 30.488 \\
(0.320-0.746) \\
p=0.001\end{array}$ \\
\hline
\end{tabular}

Notes: aA significant difference between survival data was not demonstrable based on the log-rank sum test (applies equal weight across all events) but was observed (or demonstrated a trend toward significance) using the Peto-test, which compares the early part of the survival curves. ${ }^{b}$ Most significant results based on subgroup analyses. Subgroups based on cDDD: quartile I (QI) 2,800 mg; quartile 3 (Q3) I6,800 mg. Improvement in survival observed for $>Q 3$ vs. control, vs. $<Q$ I ( $p=0.00 \mathrm{I}$ ) and vs. $\geq$ Q I- $\leq$ Q3 $(p=0.0005)$.

Abbreviations: ALS, amyotrophic lateral sclerosis; cDDD, cumulative defined daily dose; $\mathrm{Cl}$, confidence interval; HR, hazard ratio; NA, not applicable; NP, not performed; $\mathrm{NR}$, not reported; RCT, randomized controlled trial; RR, relative risk.

survival was attributable to riluzole treatment $(p<0.0001)$ and also demonstrated benefits afforded through earlier treatment in older patients and in those demonstrating a higher rate in disease progression. Thus, the median extension of survival afforded through the use of riluzole in ALS patients was 10 to $>18$ months.

3. Turner et al: ${ }^{50}$ retrospective multivariate modeling of therapeutic interventions in 841 ALS patients between 1990 and 2000. Treatment with riluzole was tested as a prognostic factor within the model $(\mathrm{n}=656$ of which data from 648 patients were analysed; 299 patients were treated with riluzole and 349 were nontreated). Median survival from symptom onset in riluzole-treated ALS patients was 51 months compared to 32 months in nontreated patients $(\log$-rank $p<0.0001)$ (Table 2). In a subgroup of 98 patients with suspect or possible ALS, median survival was 66 vs. 49 months ( $n=128$ ), respectively. Cox analysis demonstrated that riluzole therapy was an independently significant prognostic factor; relative risk of death was estimated to be $0.48(p<0.0001)$. The authors suggested that the survival benefit would be $\sim 9$ months when treated similarly to prospective RCTs, i.e., survival determined from time of enrollment rather than symptom onset.

4. Traynor et al: ${ }^{41}$ retrospective comparison undertaken on 149 riluzole-treated ALS patients with 97 nontreated ALS patients between 1996 and 2000 (database total $n=246$ ). The extension of survival afforded through the use of riluzole in ALS patients was 4.2 months (mean survival times 14.3 months after riluzole treatment vs. 10.1 months in nontreated patients) (Table 2). The effect of riluzole treatment on survival was more marked in bulbar onset ALS patients than in limb onset patients (data not shown). Analysis of risk of death associated with selected independent variables using a Cox proportional hazard model showed that bulbar onset disease and age at time diagnosis $>60$ years, but not riluzole treatment, were positively related to hazard, which suggested that the positive benefit of riluzole treatment could be related to other confounding factors.

5. Mitchell et al: ${ }^{51}$ Retrospective comparison undertaken on 148 riluzole-treated ALS patients with 327 nontreated ALS patients between 1980 and 2003 (database total $\mathrm{n}=475$ ). The median survival time in riluzole-treated patients was 3.07 years compared to 2.25 years in untreated patients (Table 2). The HR of the difference in median survival times between riluzole-treated and nontreated groups showed significance $(p<0.05)$ in the overall patient population (HR 1.66). Further analysis using the Cox model showed that survival increased significantly in patients treated with riluzole compared to those had not been treated (HR $0.20, p<0.001$ ).

6. Zoccolella et al: ${ }^{52}$ Prospective population-based investigation on the effect of riluzole on the survival of patients diagnosed with ALS between 1998 and 1999. The cohort comprised 73 ALS patients treated with riluzole and 53 nontreated patients (database total $n=126$ ). Riluzole treatment prolonged survival by 5.8 months; median survival time in riluzole-treated patients was 18.3 months compared to 12.4 months in untreated patients (Table 2). Cox multivariate 
analysis showed that riluzole treatment was associated with an improvement in survival at 12 months; HR 0.51 ( $p=0.06)$.

7. Lee et al: ${ }^{53}$ Retrospective population-based investigation on the effect of various factors including riluzole use on survival of patients diagnosed with ALS between 1999 and 2008. The cohort comprised 698 ALS patients treated with riluzole and 451 nontreated patients (database total $\mathrm{n}=1,149)$. It was reported that riluzole treatment ( $p=0.01$, log-rank), and in particular riluzole treatment with tracheostomy ( $p=0.004)$, afforded prolonged survival compared with nontreated/nontracheotomized patients (median survival times were not given and these data were based on cohorts of 553, 145, and 355 patients, respectively). Cox multivariate analysis $(n=1,149)$ showed that riluzole treatment was associated with an improvement in survival; unadjusted HR $0.32(p<0.001)$ and adjusted HR 0.34 ( $p<0.001)$ (Table 2).

8. Georgoulopoulou et al: ${ }^{54}$ prospective population-based investigation on the effect of clinical factors, riluzole, and therapeutic interventions on the survival of 193 patients diagnosed with ALS between 2000 and 2009. Based on univariate analysis, the median survival time from onset to death in patients receiving riluzole treatment $(n=133)$ was 43 months compared to 31 months in 60 nontreated patients (log-rank $p<0.01)$ (Table 2 ). The corresponding median survival times from onset to death or tracheostomy were 38 and 31 months, respectively $(\log$-rank $p=0.11)$. However, stratified analysis demonstrated a 10-15 month increase in tracheostomy-free survival and analysis of factors possibly related to survival using the Cox multivariate model showed that riluzole treatment was a strong and independent factor related to survival.

9. Knibb et al: ${ }^{55}$ prospective population-based investigation on the effect of clinical factors, riluzole, and therapeutic interventions on the survival of 575 patients diagnosed with ALS between 1990 and 2013. Patient survival was modeled as a two step process: the time from diagnosis to respiratory muscle involvement followed by the time from respiratory muscle involvement to death. The riluzole treatment group comprising 260 ALS patients was compared to 315 nontreated patients. Analyses demonstrated longer time from diagnosis to respiratory involvement in both bulbar and limb onset ALS patients who received riluzole (Table 2 ). The study concluded that use of riluzole (among other factors such as younger age at symptom onset and longer delay from onset to diagnosis) was associated with a slower progression to respiratory involvement.
10. Chen et al: ${ }^{56}$ prospective population-based investigation on the effect of various factors including riluzole use on survival of patients diagnosed with ALS between 2007 and 2013. The cohort comprised 415 ALS patients treated with riluzole and 1,125 nontreated patients (database total $n=1,540$ ). Riluzole use in the study was defined as use of riluzole for longer than 2 weeks (i.e., a cumulative defined daily dose [cDDD] of $>1,400 \mathrm{mg}$ based on DDD of $100 \mathrm{mg} / \mathrm{d}$ ). Subgroups of patients were defined based on cDDD; the cDDD of 1 and 3 quartiles was 2,800 mg (about 1-month use) and 16,800 mg (about 6-month use), respectively. The median survival time in patients receiving riluzole treatment was 67 months compared to 64 months in nontreated patients (logrank $p=0.780)$; HR 0.855 ( $p=0.167$ ) (Table 2). Despite the lack of significant differences based on the overall patient population, subgroup analysis based on cDDD revealed that survival of the "above quartile 3 " riluzole subgroup $(n=115)$ was significantly better than that of the control group (adjusted HR $0.488 p=0.001$ ); the most prominent features were increased survival, compared to nontreated subjects, from 61 months in male subjects and 59 months in the $42-58$ age group to 88 months $(p<0.006)$ and 83 months $(p=0.024)$, respectively. Similar differences were also observed when the "above quartile 3" subgroup (cDDD > 16,800 mg) was compared to "below quartile 1 " (cDDD $<2,800 \mathrm{mg}$ ) and "quartile 1 through to 3 " (cDDD $\geq 2,800 \leq 16,800 \mathrm{mg}$ ) subgroups (data not shown).

A deficiency in the RWE on riluzole relates to the fact that these studies cannot control either bias in treatment assignment or other factors, which could directly impact on survival or additional outcomes. ${ }^{57}$ Thus, there is generally imbalance between riluzole-treated and nontreated groups in terms of the key prognostic factors. In RCTs, the effects of such differences are minimized by random and blinded allocation of patients to treatment groups. Despite this, the outcome of the RWE database investigations conducted to date on riluzole in ALS patients is remarkably consistent in that they demonstrate enhanced survival in patients taking riluzole compared to nontreated patients. This is more impressive considering that these databases comprised patient populations from the UK, Ireland, Italy, USA, Taiwan, and China. Thus, in view of likely differences in health care systems and ancillary care, such as nutritional supplementation, differences in study outcomes might intuitively be expected. ${ }^{58}$ The fact that differences were not observed tends to support the relevance and value of the data. 


\section{Conclusion}

The data obtained and the subsequent meta-analysis of RCTs demonstrate that riluzole typically appears to extend survival in ALS patients by 2-3 months and increases the chance of an additional year of survival by $\sim 9 \%$. Extensive RWE from 10 clinical ALS databases, encompassing $\sim 6,000$ subjects, however, indicates that riluzole may offer significantly greater enhancement of median survival by up to 19 months. The compilation of this information should assist prescribers, patients, and carers in deciding the appropriateness of riluzole and thereby more robustly and more effectively managing the treatment of ALS.

\section{Acknowledgment}

Paracelsis Ltd/PharmaSci Consulting Ltd were invited by Martindale Pharma to conduct an independent evaluation of available clinical trial and real-world evidence on riluzole.

\section{Disclosure}

Michael Hinchcliffe is the sole director of Paracelsis Ltd and Alan Smith is a member of the Scientific Advisory Board of PharmaSci Consulting Ltd. The authors are solely responsible for the article content. The authors report no other conflicts of interest in this work.

\section{References}

1. Brayfield A, editor. Martindale: The Complete Drug Reference. 37th ed. London, England, UK: Pharmaceutical Press; 2011. Available from https://www.medicinescomplete.com. Accessed January 14, 2017.

2. NCBI (National Center for Biotechnology Information) [webpage on the Internet]. PubChem Compound Database; CID=5070 (Riluzole). Available from: https://pubchem.ncbi.nlm.nih.gov/compound/ riluzole\#section=Top. Accessed January 14, 2017.

3. Drugs.com [webpage on the Internet]. Riluzole Information from Drugs. com; c2000-17. Available from: https:/www.drugs.com/cdi/riluzole. html. Accessed January 14, 2017.

4. eMC [webpage on the Internet]. Rilutek $50 \mathrm{mg}$ film-coated tablets summary of product characteristics (SPC) (Sanofi). Available from: http://www.medicines.org.uk/emc/medicine/1672. Accessed January 14, 2017.

5. Kuhnlein P, Gdynia HJ, Sperfeld AD, et al. Diagnosis and treatment of bulbar symptoms in amyotrophic lateral sclerosis. Nat Clin Pract Neurol. 2008;4(7):366-374.

6. Wijesekera LC, Leigh PN. Amyotrophic lateral sclerosis. Orphanet $J$ Rare Dis. 2009;4:3.

7. Andersen PM, Abrahams S, Borasio GD, et al. EFNS guidelines on the clinical management of amyotrophic lateral sclerosis (MALS) - revised report of an EFNS task force. Eur J Neurol. 2012;19(3):360-375.

8. Miller RG, Mitchell JD, Moore DH. Riluzole for amyotrophic lateral sclerosis (ALS)/motor neuron disease (MND). Cochrane Database Syst Rev. 2012;(3):CD001447.

9. Pratt AJ, Getzoff ED, Perry JJ. Amyotrophic lateral sclerosis: update and new developments. Degener Neurol Neuromuscul Dis. 2012;(2):1-14

10. Calvo AC, Manzano R, Mendonca DM, Munoz MJ, Zaragoza P, Osta R. Amyotrophic lateral sclerosis: a focus on disease progression. Biomed Res Int. 2014;2014:925101.
11. Nichols NL, Van Dyke J, Nashold L, Satriotomo I, Suzuki M, Mitchell GS. Ventilatory control in ALS. Respir Physiol Neurobiol. 2013;189(2):429-437.

12. Ingre C, Roos PM, Piehl F, Kamel F, Fang F. Risk factors for amyotrophic lateral sclerosis. Clin Epidemiol. 2015;7:181-193.

13. Chio A, Logroscino G, Traynor BJ, et al. Global epidemiology of amyotrophic lateral sclerosis: a systematic review of the published literature. Neuroepidemiology. 2013;41(2):118-130.

14. Mehta P, Kaye W, Bryan L, et al. Prevalence of amyotrophic lateral sclerosis United States, 2012-2013. MMWR Surveill Summ. 2016;65(No.SS-8):1-12.

15. Arthur KC, Calvo A, Price TR, Geiger JT, Chiò A, Traynor BJ. Projected increase in amyotrophic lateral sclerosis from 2015 to 2040. Nat Commun. 2016;7:12408.

16. Gordon PH. Amyotrophic lateral sclerosis: pathophysiology, diagnosis and management. CNS Drugs. 2011;25(1):1-15.

17. Beal MF. Bioenergetics in oxidative damage in neurodegenerative diseases. In: Fiskum G, editor. Neurodegenerative Diseases: Molecular and Cellular Mechanisms and Therapeutic Advances (Proceedings of the Fifteenth Washington International Spring Symposium at The George Washington University; May 15-17, 1995, Washington, DC; New York, NY: Springer Science+Business Media; 1996:171-180.

18. Platt SR. The role of glutamate in central nervous system health and disease - a review. Vet J. 2007;173(2):278-286.

19. Ludolph A, Drory V, Hardiman O, et al. A revision of the El Escorial criteria - 2015. Amyotroph Lateral Scler Frontotemporal Degener. 2015;16(5-6):291-292.

20. Gaber TA-ZK, Mehmood Z, Siringwani H. Riluzole. Prog Neurol Psychiatry. 2016;20:32-33.

21. NICE (National Institute for Clinical Excellence). Guidance on the Use of Riluzole (Rilutek) for the Treatment of Motor Neurone Disease. Vol. 20. 2001. Technology Appraisal Guidance. Available from: https:// www.nice.org.uk/Guidance/ta20. Accessed January 14, 2017.

22. Zarate CA, Manji HK. Riluzole in psychiatry: a systematic review of the literature. Expert Opin Drug Metab Toxicol. 2008;4(9):1223-1234.

23. Medicines.org [database on the Internet]. DataPharm, UK: electronic medicines compendium (eMC) for riluzole. Available from: https:// www.medicines.org.uk/emc/search. Accessed January 14, 2017.

24. Dyer AM, Smith A. Riluzole $5 \mathrm{mg} / \mathrm{mL}$ oral suspension: for optimized drug delivery in amyotrophic lateral sclerosis. Drug Des Devel Ther. 2017;11:59-64.

25. Keating GM. Riluzole oral suspension in amyotrophic lateral sclerosis: a guide to its use. Drugs Ther Perspect. 2016;32(7):282-286.

26. Bensimon G, Lacomblez L, Meininger V. A controlled trial of riluzole in amyotrophic lateral sclerosis. $N$ Engl J Med. 1994;330(9):585-591.

27. Lacomblez L, Bensimon G, Leigh PN, Guillet P, Meininger V. Doseranging study of riluzole in amyotrophic lateral sclerosis. Lancet. 1996;347:1425-1431.

28. Yanagisawa N, Tashiro K, Tohgi H, et al. Efficacy and safety of riluzole in patients with amyotrophic lateral sclerosis: double-blind placebocontrolled study in Japan. Igakuno Ayumi. 1997;182:851-866.

29. Bensimon G, Lacomblez L, Delumeau JC, et al; Riluzole/ALS Study Group II. A study of riluzole in the treatment of advanced stage or elderly patients with amyotrophic lateral sclerosis. J Neurol. 2002;249(5):609-615.

30. Ghaleiha A, Mohammadi E, Mohammadi M-R, et al. Riluzole as an adjunctive therapy to risperidone for the treatment of irritability in children with autistic disorder: a double-blind, placebo-controlled, randomized trial. Pediatric Drugs. 2013;15(6):505-514.

31. Farokhnia M, Sabzabadi M, Pourmahmoud H, et al. A double-blind, placebo controlled, randomized trial of riluzole as an adjunct to risperidone for treatment of negative symptoms in patients with chronic schizophrenia. Psychopharmacology. 2014;231(3):533-542.

32. Rajasekaran S, Aiyer SN, Shetty AP, Kanna RM, Maheswaran A, Shetty JY. Effectiveness of riluzole as a pharmacotherapeutic treatment option for early cervical myelopathy: a double-blinded, placebo-controlled randomised controlled trial. Eur Spine J. 2016;25(6):1830-1835. 
33. Stewart A, Sandercock J, Bryan S, et al. The clinical effectiveness and cost-effectiveness of riluzole for motor neurone disease: a rapid and systematic review. Health Technol Assess. 2001;5(2):1-97.

34. Standaert DG, Roberson ED. Treatment of central nervous system degenerative disorders. In: Brunton L, Chabner BA, Knollman B, editors. Goodman and Gilman's The Pharmacological Basis of Therapeutics. 12 ed. (Chap. 22). McGraw-Hill; 2011.

35. Moore A, McQuay HJ. What is an NNT? . Vol. 1; Issue No. 1. England: Hayward Medical Communications Ltd. Available from: http://www. bandolier.org.uk/painres/download/whatis\%20copy/NNT.pdf. Accessed March 30, 2017.

36. Absher JR. Riluzole increased survival in amyotrophic lateral sclerosis. ACP J Club. 1994;121:9.

37. Demaerschalk B; the UWO Evidence Based Neurology Group. Riluzole Appears to Minimally Improve Survival in ALS. All Other Therapeutic Trials of Anti-Glutamatergic and Anti-Excitotoxicity Agents Reveal no Significant Effect; 1999. Available from: http://www.cnsuwo.ca/ebn/downloads/cats/2010/CNS-EBN_catdocument_2010-07-JUL-30_riluzole-appears-to-minimally-improvesurvival-in-als-all-other-therapeutic-trials-of_1FFE9.pdf. Accessed March 30, 2017.

38. ABPI (The Association of the British Pharmaceutical Industry). The Vision for Real World Data - Harnessing the Opportunities in the UK. London, UK: ABPI; 2011. Available from: http://www.abpi.org.uk/ our-work/library/industry/documents/vision-for-real-world-data.pdf. Accessed January 12, 2017.

39. IOM (Institute of Medicine). Crossing the Quality Chasm: A New Health System for the $21^{\text {st }}$ Century. Washington, DC: National Academy Press; 2001.

40. Booth CM, Tannock IF. Randomised controlled trials and populationbased observational research: partners in the evolution of medical evidence. Br J Cancer. 2014;110(3):551-555.

41. Traynor BJ, Alexander M, Corr B, Frost E, Hardiman O. An outcome study of riluzole in amyotrophic lateral sclerosis - a population-based study in Ireland, 1996-2000. J Neurol. 2003;250(4):473-479.

42. Fleurence RL, Naci H, Jansen JP. The critical role of observational evidence in comparative effectiveness research. Health Aff (Millwood). 2010;29(10):1826-1833.

43. Clay RA. More than one way to measure - randomized clinical trials have their place, but critics argue that researchers would get better results if they also embraced other methodologies. Monitor Psychol. 2010;41(8):52.

44. Bonnelye G, Miniuks A, Goncalves A [webpage on the Internet]. The importance of real-world data to the pharma industry. PMlive. 2015. http://www.pmlive.com/pharma_thought_leadership/the_importance_of_real-world_data_to_the_pharma_industry_740092.Accessed January 12, 2017.

45. Fiminska $Z$ [webpage on the Internet]. Real world evidence: maximize benefits to healthcare. Eye Pharma. 2015. Available from: http://social. eyeforpharma.com/market-access/real-world-evidence-maximizebenefits-healthcare. Accessed January 12, 2017.
46. Hubbard TE, Paradis R. Real World Evidence: A New Era for Health Care Innovation. Massachusetts: The Network For Excellence In Health Innovation; 2015. Available from: http://www.nehi.net/ publications/66-real-world-evidence-a-new-era-for-health-care-innovation/view. Accessed December 18, 2016.

47. Fellows M. Real world evidence: a reality check for pharma? Pharmafocus. 2016;18(9):14-17.

48. Meininger V, Lacomblez L, Salachas F. What has changed with riluzole? J Neurol. 2000;247(suppl 6):VI/19-22.

49. Brooks BR, Belden DS, Roelke K, et al. Survival in non-riluzole treated amyotrophic lateral sclerosis (ALS) - motor neuron disease (MND) patients with disease onset before and since 1996 is identical: a clinicbased epidemiological study. Amyotroph Lateral Scler Other Motor Neuron Disord. 2001;2:60-61.

50. Turner MR, Bakker M, Sham P, Shaw CE, Leigh PN, Al-Chalabi A. Prognostic modelling of therapeutic interventions in amyotrophic lateral sclerosis. Amyotroph Lateral Scler Other Motor Neuron Disord. 2002;3(1):15-21.

51. Mitchell JD, O'Brien MR, Joshi M. Audit of outcomes in motor neuron disease (MND) patients treated with riluzole. Amyotroph Lateral Scler. 2006;7(2):67-71.

52. Zoccolella S, Beghi E, Palagano G, et al; SLAP Registry. Riluzole and amyotrophic lateral sclerosis survival: a population-based study in southern Italy. Eur J Neurol. 2007;14(3):262-268.

53. Lee CT-C, Chiu Y-W, Wang K-C, et al. Riluzole and prognostic factors in amyotrophic lateral sclerosis long-term and short-term survival: a population-based study of 1149 Cases in Taiwan. J Epidemiol. 2013;23(1):35-40.

54. Georgoulopoulou E, Fini N, Vinceti M, et al. The impact of clinical factors, riluzole and therapeutic interventions on ALS survival: a population based study in Modena, Italy. Amyotroph Lateral Scler Frontotemporal Degener. 2013;14(5-6):338-345.

55. Knibb JA, Keren N, Kulka A, et al. A clinical tool for predicting survival in ALS. J Neurol Neurosurg Psychiatry. 2016;87(12): 1361-1367.

56. Chen L, Liu X, Tang L, Zhang N, Fan D. Long-term use of riluzole could improve the prognosis of sporadic amyotrophic lateral sclerosis patients: a real-world cohort study in China. Front Aging Neurosci. 2016; $8: 246$.

57. Armon C, Guiloff RJ, Bedlack R. Limitations of inferences from observational databases in amyotrophic lateral sclerosis: all that glitters is not gold. Amyotroph Lateral Scler Other Motor Neuron Disord. 2002;3(3):109-112.

58. Meininger V. Database analyses: a reply. Amyotroph Lateral Scler Other Motor Neuron Disord. 2002;3(3):113.

59. Lacomblez L, Bensimon G, Leigh PN, Guillet P, Meininger V. Riluzole and amyotrophic lateral sclerosis (Authors reply). Lancet. 1996;348:336-337.

60. Riviere M, Meininger V, Zeisser P, Munsat T. An analysis of extended survival in patients with amyotrophic lateral sclerosis treated with riluzole. Arch Neurol. 1998;55(4):526-528.
Degenerative Neurological and Neuromuscular Disease

\section{Publish your work in this journal}

Degenerative Neurological and Neuromuscular Disease is an international, peer-reviewed, open access journal focusing on research into degenerative neurological and neuromuscular disease, identification of therapeutic targets and the optimal use of preventative and integrated treatment interventions to achieve improved outcomes, enhanced

\section{Dovepress}

survival and quality of life for the patient. The manuscript management system is completely online and includes a very quick and fair peer-review system. Visit http://www.dovepress.com/testimonials.php to read real quotes from published authors. 